\title{
The Soft Systems Methodology and its Suitability for Portuguese Cooperation
}

Carlos Sangreman

Raquel Faria

Carlos Sangreman

Retired lecturer at the University of Aveiro

Researcher in the Centre for Studies on Africa,

Asia and Latin America (CEsA/ISEG/UL).

carlos.sangreman@ua.pt

Raquel Faria

Researcher in the CESA/ISEG/UL.

raquelfaria@ua.pt 


\begin{abstract}
:
Portuguese Cooperation is a system with a minimal structure (basic concepts, vision, principles and explicit values that can vary over time; many actors involved; with a structure, procedures and instruments that have not stabilised since it began to take shape in the period after the 1974 revolution; and activities and actors that are more stable, though with variations over time). As such, it is like the so-called soft systems with characteristics of the Soft Systems Methodology (SSM). The organisation fulfils, therefore, some of the requirements of the SSM.
\end{abstract}

\section{Introduction}

This article took shape after 2 (two) major innovations that occurred in the Clusters for Cooperation project, the main aim of which was to lead to confirmation (or decide that there was no basis for confirmation) of the extent to which the hypothesis relating to the concept and practice of clusters in Cooperation for Development (in Angola-ECunha-Huambo, Mozambique island, Maubara-Ermera-Timor Leste and the São Tomé e Príncipe islands) would provide a positive response to the issue of reaching better coherence, harmonisation and alignment, in accordance with the current international consensus. This response could also have a "boomerang" effect on Portuguese cooperation and come to influence its practices and operational procedures.

The project, then, looked at the need to set out a methodology which would make it possible to reach an overall understanding of Cooperation and a standardised set of what are called individual values, that is, those of the actors in the field of Cooperation. The conclusion was that SSM would be the best option. This was not only because of its distinct procedures and instruments, but also because of the very nature of Portuguese cooperation, which has much in common with the characteristics of soft systems.

One of the other references for the choice of SSM in this area was the doctoral thesis A Cooperação Portuguesa no contexto da Cooperação Internacional para o Desenvolvimento (1998-2012): um ensaio de modelização [The Portuguese Cooperation in the context of International Development Cooperation (1998-2012): an attempt at modelling].

In fact, with these 2 (two) research projects (Clusters and the doctoral thesis), we were able to give a solid contribution to Portuguese Cooperation. We were able to put in place a methodology that could give us an overall view of Cooperation, and we were also able to identify a set of values that had been up till then unidentified: the values that the actors in Portuguese Cooperation ${ }^{1}$ consider to be the main points of reference for individual and collective action, that is, the so-called individual values.

It should be noted that up to this point in time, in the literature and in the wider area of official documentation, the predominant values, were those identified by governments, inspired to a greater or lesser degree by documents issuing form the European Union (EU) and the Development Assistance Committee (DAC) of the Organisation for Economic Cooperation and Development (OECD). 
In the light of these points, the idea behind this article was to show how SSM could be put in place in Portuguese Cooperation (given that this methodology is normally used only in business management rather than political scenarios). Alongside this, the intention was to provide a very succinct overview of the values identified by those working in Cooperation.

\section{Portuguese Cooperation}

The policy underlying Portuguese Cooperation since it began (in the period after the April 25 revolution in 1974) has been based on a decentralised set-up ${ }^{2}$, and has focused from the outset on relations with the African countries where Portuguese is the official language (the so-called PALOPs) and, more recently, with East Timor. These 2 (two) geographical areas became the dominant points in the policy of Cooperation, with other countries in the statistics merely relating to the opening of credit lines for companies (Morocco) or military and policing missions (in the Balkans, Afghanistan, ...).

The institutional framework for Cooperation goes back to the 70s (the seventies), but the development of an effective programme only began in 1985, with the creation of post of Secretary of State for Foreign Affairs and Cooperation. The situation was only fully consolidated in 1999 with the first strategic guidelines [The Council of Ministers Resolution (RCM) no. 43/99, Portuguese Cooperation on the threshold of the 21st century]. Six years later, RCM no. 196/2005 (A strategic vision for Portuguese Cooperation) was a clear continuation and adaptation of this, replaced in 2014 by the document entitled The strategic concept of Portuguese Cooperation - RCM no. 17/2014). This followed the 2012 merger of the functions of Cooperation, the dissemination of the Portuguese language and economic diplomacy in the same State structure - Camões, ICL - under the aegis of the Ministry of Foreign Affairs (MNE).

In terms of being an aspect of foreign policy, Portuguese Cooperation is governed by a set of general values around the ideas of peace, solidarity between peoples, democracy, respect for human rights, promotion of the Portuguese language, covering also the issue of environmental protection (Sangreman 2009).

Along with this, it covers a wide range of objectives based on the priorities set out in the 2 (two) strategic documents, among them: bolstering the democratic system and the rule of law; cutting down poverty (by boosting socio-economic conditions and the development of suitable educational infrastructures); stimula-
These characteristics and the need to put in place a methodology that not only allows for an overall understanding of Cooperation for Development, where analyses of new problem situations can be inserted, but also for a standardised set of values that those involved in cooperation consider the right ones. Our aim in the present paper, therefore, is specifically to see how SSM can be implemented, using as a basis the phases and instruments of the system itself.

\section{KEY WORDS:}

Portuguese cooperation; SSM; values. 
ting economic growth; promoting dialogue, regional integration and a «European partnership for human development» (Palma 2002).

These differing values and objectives that govern action have not hindered the development of a series of instruments over the years within the scope of Cooperation, among them the Programas Indicativos de Cooperação (Indicative Programmes of Cooperation - PIC), the Programas Integrados de Cooperação (Integrated Development Programmes), the Delegações Técnicas de Cooperação (Technical Delegations for Cooperation) and institutions such as the Agência Portuguesa de Apoio ao Desenvolvimento (Portuguese Agency for Support in Development APAD) or the Society for Financing Development (SOFID).

The Portuguese Cooperation system has undergone a number of structural changes, among them those occurring in 2002 and 2003, when APAD was closed down and there was a return to the model based on a single institution to coordinate cooperation the Portuguese Institute for Support to Development (IPAD). This took it back to the administrative culture of a general directorate in the public administration sector; and the most recent, occasioned by the merger of IPAD and the Camões Institute, a public institution to promote the expansion of the Portuguese language across the world. This led to the new Camões-Institute for Cooperation and Language (Camões-ICL), which came into being early in 2012 (Decree Law no. 21/2012, of 30 January).

Note that this merger, defined as problematic situation, allows, as will be demonstrated, the application of SSM to the Portuguese Cooperation.

\section{A Soft Systems Methodology (SSM)}

The SSM is a management method developed by Peter Checkland. It is a procedure (organised, flexible and based on systemic thinking) enabling reflection on actions that need to be taken to put in place organisational changes that are perceived as favourable to improvement in situations considered to be problematical (Checkland 1981; Checkland and Scholes 1990). What is involved, therefore, is the creation of a structured thinking, building on the basic ideas underlying systems, so as to think about what it would be appropriate to do if faced with complex social situations that are very common in the day-to-day running of organisations where there is perception that changes are needed to alleviate the tensions involved (Checkland and Poulter 2006). 
The SSM, as it is put forward, is seen not only as a way of solving organisational problems but also, and mainly, as a way of fostering the learning process among the actors involved, increasing the range of organisational features that they look at closely, starting from the explicit expression and the debate around a wide array of different perspectives relating to the same problem points (Checkland 1981; Checkland and Poulter 2006).

Taken in this way, hard thought sees the world as one containing systems the performance of which can be optimised by applying systematic procedures, while the theoretical current of Soft Systems Thinking sees the world as real but extremely complex and problematic. In order to get to know it better and improve it, it is necessary to work in a systemic world of logical analyses with the emphasis on learning from the actors involved (Checkland and Scholes 1990; Checkland and Poulter 2006).

This method was developed from the realisation that hard systemic thought and therefore its disciplines/methods - such as Operational Research, Systems Engineering, and Systems Analysis - were limited to solving specific problems, among them badly structured and badly defined problems around which there is no consensus.

The aim of SSM is to enrich the understanding of a specific situation without worrying directly about the algorithmic solution to a supposed problem. The method can be applied mainly to situations where the issue is not so much "how to do something" as "what should be done" (Pidd 1998).

It is a systemic method aiming to identify structure problem situations characterised by a definition that involves different perspectives.

Given this, we can define the SSM as a way of "structuring problems" rather than "solving problems", since the method focuses mainly on unstructured problem situations characterised by disagreements and uncertainties as to the nature of the context of the problem (Clarke et al. 1999).

One of the many features of this type of problem is the persistent search for visual expression through graphics and images of the processes or situations (the socalled rich picture). These graphics are extremely useful to get an overall view of the system that is being studied but they tend to be too personalised and become difficult to understand for everyone except the authors themselves.

It should be noted that making a rich picture means creating a graphic representation or drawing of how the problem situation at issue is perceived by the authors, and the tendency to personalisation derives from this fact. 
In spite of this tendency to become personal, it is important to realise that development and implementation of SSM depends a great deal on how it is applied by the person using and above all interpreting it. Given this, we are going to give our own interpretation of the phases of the methodology laid out by Peter Checkland and other authors that we have mentioned. Our point of reference is the description of these phases as these authors developed them over time.

The aim of SSM is to reach an understanding of the basic situation at time $t$ as it refers to a system built from a number of analyses with varying focus, and an operating model that makes it possible to look at a "problematic situation" or a "problem" and come up with an assessment of how to go about a change, the actions needed to solve the problem, and perception of how this solution will affect the understanding of the basic situation at the point in time $t+1$.

For this reading of the understanding of the basic situation and the definition of the problematic situation, the method proposes a set of 3 (three) (A1, A2 and A3) analysis. A1 being the analysis of the existing situation, A2, focusing on the external social and cultural environment and A3 focusing on the internal social environment, including the power relationships between those most directly involved in the system under review. In the case of A3, it involves an analysis of the different public and private actors involved in the "field".

The Soft Systems Methodology and its suitability for Portuguese Cooperation

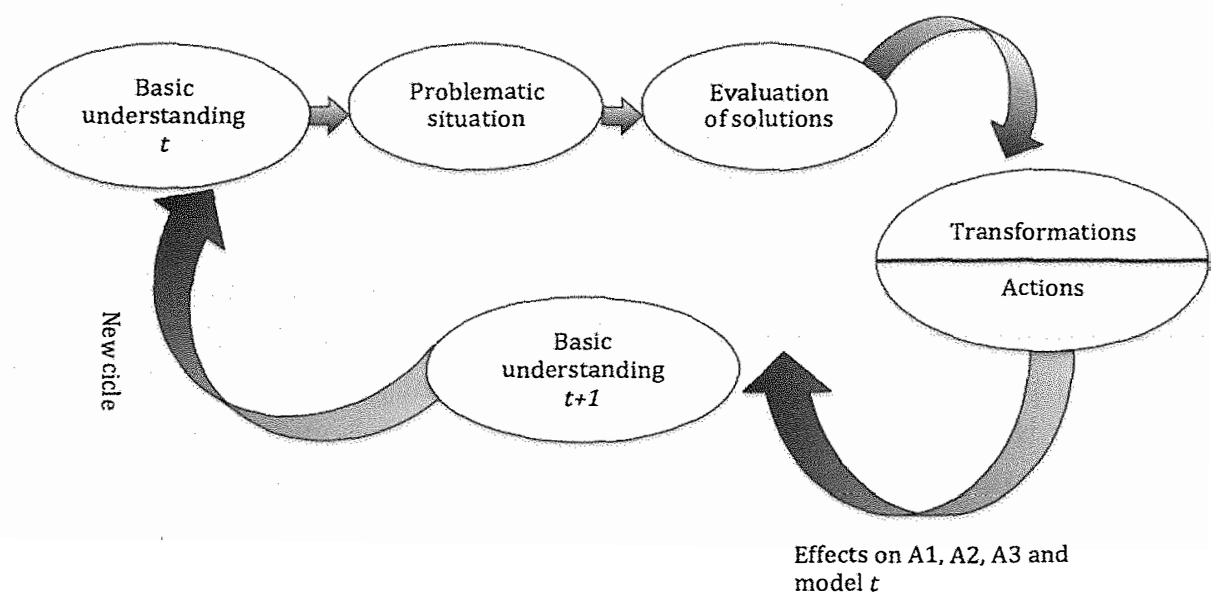

SCHEME 1 
For the sake of coherence, it is necessary to specify a series of concepts and variables, summed up in the mnemonic CATWOE (with our own additions in brackets). These are (C) Clients, (beneficiaries, partners); (A) actors, (those involved); (T) transformation (evolution); (W) weltanschanung (a socio-political view of the system, including ethical values); (O) owners (main actors who have the capacity to structure the basic situation) ${ }^{3}$; (E) environmental constraints (including relevant technology). There are also the issues set out under the acronym PQR (What does the system do? How does it do it? Why does it do it? Or, in other words "Do P by means of Q to get to $\mathrm{R}^{\prime \prime}$ ).

The combination of CATWOE + PQR is defined as root definition.

The analysis of the existing situation from the concepts of the root definition (A1) complete the items needed for an understanding of the basic situation. Our understanding of A1 is that it is mainly a factual analysis of the system under review, with features that relate more to description that to evaluation, using of statistical information taken from a range of sources. It may include elements that are not really expressly defined by the actors, generally speaking, as the values that pertain at time $t$ or the capacity of the main actors to be flexible in structuring the whole system.

The analysis is related to the intervention itself, as this aims to improve the situation characterised as problematic.

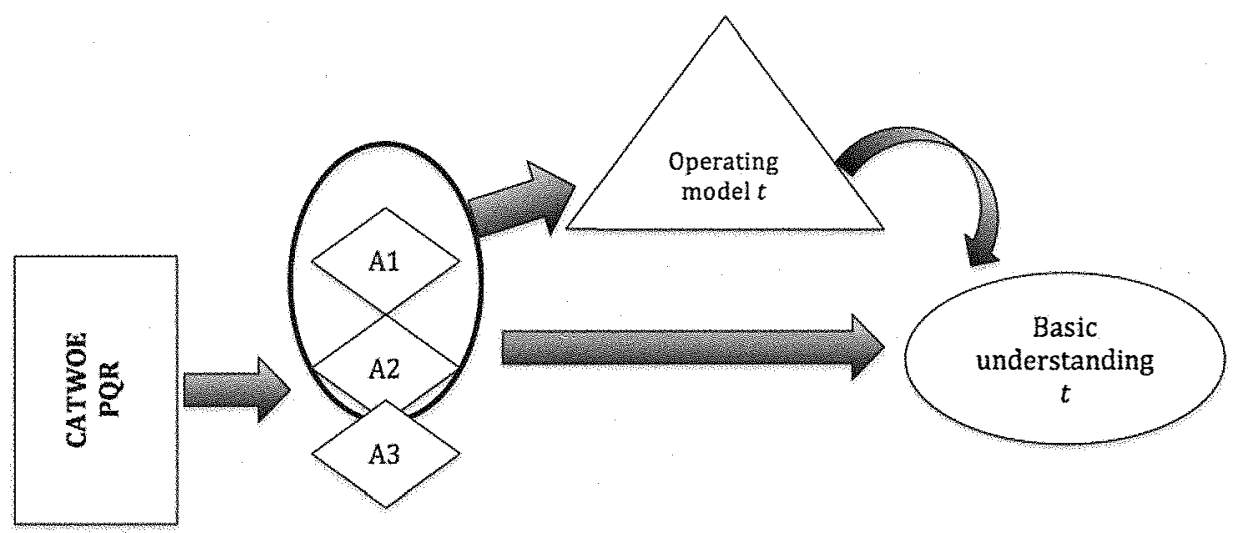

SCHEME 2 
A working model ${ }^{4}$ of the situation is put together, and for this, the functions of those involved have to be defined. This conceptual model, according to the SSM terminology, is used to perceive what are the effects of the solution found for the problem in a reading of the basic situation at a different moment in time.

These models are extremely important not only for comparing the activities (expressed in verbs) which make up the problem situation but also for identifying the changes that are seen as desirable and culturally possible. These will be the actions that improve the problematic situation that is at issue.

Peter Checkland considers that these models should be expressed as synthetic behaviour, using verbs, as in the example "He does $\mathrm{Y}$ by financing $\mathrm{Z}$ to reach $\mathrm{X}$ ".

In other words, we are looking for a function of the behaviour of the actors individually and as a whole. That is, we are looking for a function that acts as a synthesis of the system that will have in its subsystems the functions of the actors that make up the system. This could, at least in part, make up the content of the replies to the questions in the PQR acronym.

In order to control or improve these models, Checkland defined a set of 5 (five) measurements of performance, or criteria of evaluation, 2 (two) of which are

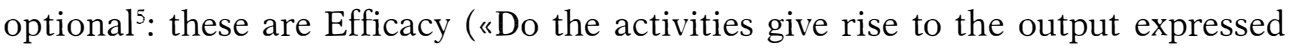
in the process?»), Efficiency («Is the least amount of resources being used?»), Effectiveness («Is the right thing being done? Will our objectives be reached in the long term?»), Ethics ( IIs what is being done morally correct?») and Elegance ( Is a process aesthetically agreeable?») (Checkland, Forbes and Martin in Mirijamdotter and Bergvall-Käreborn 2006, 83).

The use of SSM culminates in the desirable and culturally possible changes already mentioned. They come after the comparison ${ }^{6}$ between the activities that make up the conceptual model and the problem situation in 4 (four) distinct ways: an informal discussion with the stakeholders; a formal questionnaire; a description of a given scenario based on the "functioning" of the conceptual model; and lastly, "the attempt to model the real world with the same structure as the conceptual model» (Checkland in Nunes 2008, 73-74).

The SSM, as methodology that has been developed and improved over the years (as evidenced by the various models), has received positive and negative critics as a result of the analysis and comments made by a group of authors. 
In relation to the first, Patching is one of the stands out. For him, the use of SSM brings a number of benefits, including:

- The open discussion between the main actors of a certain problematic situation encourages a joint ownership of the solutions developed;

- Technological solutions are not imposed (Patching in Bellini, Rech and Borenstein, 2004, 6).

- On the other hand, Marcia Salner (1999), while recognizing the importance of the work developed, identifies some negative points, namely:

- An unnecessary polarization between the Hard and Soft Systemic Thinking;

- Limited theoretical basis for the social and political descriptions and analysis of human nature systems;

- Lack of critical perspective to the ethical and valid action definition in the study of interventions in human systems;

- The empirical basis for claiming the results obtained with the investigation, it was too little considered;

- Conflation of the structures and management functions, consulting and research in human systems environments.

\section{The SSM and Portuguese Cooperation: suitability}

Portuguese Cooperation is a relatively unstructured system (here are basic concepts, vision, principles and explicit values that can vary over time; many public actors (ministries, courts, institutes, municipalities, etc.) and private (NGOs, foundations, universities, polytechnic institutes, hospitals, friends groups, etc. $)^{7}$ involved; with a structure, procedures and instruments that have not stabilised since it began to take shape in the period after the 1974 revolution; and activities and actors that are more stable, though with variations over time, and as such it is like the soft systems (systems of human activity with a number of different actors and distinct ways of seeing the world) that underlie the notion of SSM. In addition, the various phases and instruments of the SSM allow us to clearly identify the essential elements in the field of Cooperation. We therefore consider the SSM the best option, given the need to put in place a methodology that not only allows for an overall understanding of Cooperation for Development where analyses of 
new problem situations can be inserted, but also for a standardised set of values that those involved in cooperation consider the right ones to be adopted for Portuguese cooperation.

For what we consider to be a model for Portuguese Cooperation, we have followed SSM procedures and borne in mind all the information mentioned above. This has led us to following visual expression for the model:

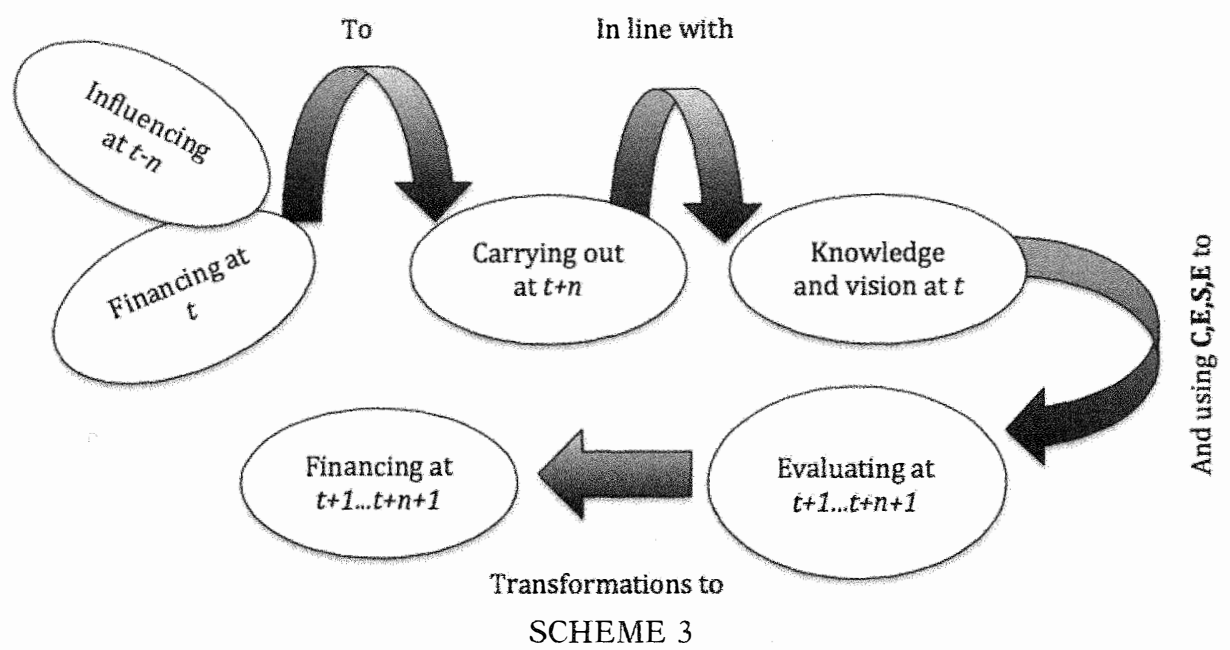

This model fits the PQR acronym, since it can be applied to Cooperation using the idea that we have to "Finance and influence $(\mathrm{P})$ in line with the knowledge and existing vision $(\mathrm{Q})$ to carry out $(\mathrm{R})$ " or "Finance and influence $(\mathrm{P})$ according to the knowledge (that the A1, A2 and A3 analysis allow) and the existing vision $(\mathrm{Q})$, to execute $(\mathrm{R})$, and evaluate before deciding what changes should be made to resume financing and influence".

The criteria for assessing the solutions have to be chosen in line with the specific situation and the following from among the standard points of reference: effectiveness, efficiency, sustainability, coherence, impact, ethics..., or others suited to the system under review.

For example, in terms of the system of International Cooperation for Development, the criterion of suitability or sustainability comes after the end of external financing. 
The basic reading on Portuguese Cooperation that we are attempting to define here starts specifically from a concept of the general system of Cooperation as a soft system, as already mentioned, and the criteria defined in terms of a logical framework can only go some way towards an evaluation. As for the standards set out by DAC/OECD in 2006, they use a wider concept of evaluation including concepts relating to the justification, aim and objectives of the evaluation, a definition of the parameters, the context, methods and sources of information, independence, standards or ethics, quality and the pertinence of the results. The very scope of this, however, also implies a lower operational level in the evaluation of a specific action.

Given this, our proposal comprises 4 (four) criteria which act as an "umbrella", and which can and should be broken down into greater detail in accordance with these system, subsystem, programme, project or action in the Cooperation under review: coherence, efficiency, sustainability and effectiveness (C,E,S,E). These are related with the harmonisation, alignment and orientation of the results (Paris Declaration of 2005) for beneficiaries and financing organisations. This, however, must also relate to the procedures, the institutional stability and the governance of all the partners, bearing in mind also, of course, the relative nature of the situations.

In other words, it is possible to analyse the instability of the overall system of Portuguese Cooperation, deriving from the average amount of time during which the work was in the hands of the senior management of the coordinating bodies or the Secretaries of State for Foreign Affairs and Cooperation (SENEC), don't forgetting that Portugal is a stable and not a fragile State.

Coherence is related to the values adopted by the public and private actors as expressed in public policies, and the statutes of other organisations involved. From a more micro angle, it relates to the range of actions backed by a financing body related with their priorities. It is enough to consult the list of support provided by IPAD over the last few years in the Diário da República (Government Gazette - DR) to understand the importance of this criterion, given the difficulty in understanding the reasoning behind many of the supports.

We then defined a specific problem situation to try and put in place the instruments made available by the SSM, and then check them through the various phases suggested in the methodology.

We defined as a problematic situation the effect that might be made on Cooperation as a whole by changing the nature of the institution mainly responsible for 
configuring the entire system (including the actors to the outside environment), and we found that it was possible to use all the tools (rich picture, CATWOE, PQR, the conceptual model and so on), and it was also possible to follow the various phases that were put in place on the basis of SSM representations. This culminated in the cycle of research/learning made up of 5 (five) phases (the theoretical reference and methodology underlying the creation of the model).

\section{Case study (summary of the main stages of implementation of SSM)}

\section{Problematic situation:}

Merger of 2 (two) organisms (IPAD and Camões Institute in Camões-ICL) which until then had different goals and its impact on Portuguese Cooperation system. However, the problematic of the situation it is not so much in the different goals that both organisms contemplated or in the importance and influence they held with the Cooperation system, wherein the Camões Institute had no Cooperation activity by the DAC criteria that were prevailing in the last ratings and recommendations [the promotion of language as an end in itself is not considered Official Development Assistance (ODA), in the sense that this should not be used for this purpose, but rather to promote development (DAC/OECD 2010; 2013)].

It's in the impact it will have a change of nature of the main configurator of the entire system, leading us to question about the effect it will have on all the Cooperation sector (or in the terminology of SSM will focus on the letter O of mnemonic CATWOE influencing analysis A1, A2 and A3).

This merger seems to us controversial, since it contradicts precisely one of the main DAC's recommendations ["the ODA (...) should be a means to help achieve development in Portuguese-speaking countries, not to promote the Portuguese language as an end itself» (DAC/OECD 2010, 12)], which is consolidated with the Major Planning Options for 2012-2015 [Law no. 64-A/2011, of 30 December], where the promotion and dissemination of the language is a goal to follow in Cooperation.

In addition, and as a consequence of the Cooperation strategy approved in 2014, economic diplomacy has become a priority (as will have occasion to see in Analysis 3$)$. 
We note that the language and economic diplomacy become priority for the Cooperation policies and external action, which leads us to question the importance given to cooperation and, above all, how the relationship will be between the 3 (three) areas, once that, in our view, this is not explicit in the current strategy (Strategic Concept of the Portuguese Cooperation 2014-2020).

\section{Analysis 1:}

As a direct client we identify the Portuguese Government, which aims a more effective and efficient Cooperation, and as beneficiaries and indirect partners, those interested in Portuguese territory (eg. the Portuguese Platform of NGDOs, universities or foundations) and in the beneficiary countries.

Should be noted that, like those interested in the country and in the beneficiary countries, our direct client is, also, the holder of the problem, a second level. The Camões-ICL is itself, given the situation under review, the holder of the main problem.

A detailed analysis of the factual situation involves elements as the existing human resources, public funds (private estimates despite being small) earmarked in the State budget for Cooperation and organizational resources (institutions, instruments, etc.).

\section{Analysis 2:}

The social system which characterizes the problematic situation is composed by the Portuguese Government, Camões-ICL and those interested (national and in the beneficiary countries).

These, in the context of Portuguese Cooperation, act based on a set of general and individual values, and a wide range of standards that have been previously defined and established inside and outside the Cooperation system, including the guidelines of the DAC/OECD, EU and resolutions adopted at the United Nations.

In relation to the first, through the existing literature, easily identifies solidarity, peace, promoting and consolidating democracy and the rule of law, respect for human rights, environmental conservation and protection of the national language (Sangreman 2009) as general values of Portuguese Cooperation. 
In contrast, the individual values were not as easy to identify, because there was no study directly aimed at this type of values. So, we attempted to reach a standardised set of individual values of the actors involved in Cooperation, and, as mentioned already, always came from top government officials, inspired to a greater or lesser extent by EU and DAC/OECD documents. For this, we developed a questionnaire based on the theory of Schwartz of Human Values, in the questionnaire model developed by him and Tamayo (1993), in the questionnaire method developed by Ronald Inglehart applied to Portugal (available at World Values Survey) and also the Code of Ethics of the IPAD and the Code of Conduct of the European Confederation of Relief and Development NGOs (CONCORD).

This questionnaire, which answered 422 people, has been available for 4 (four) weeks ${ }^{9}$ on the on-line platform SurveyMonkey. Was sent to all contacts listed in the files of Forum for Development Cooperation (FCD), the Centre for Studies on Africa, Asia and Latin America (CEsA), the Centre for African Studies (CEA) and also disclosed via online by CEsA, CEA and the Portuguese Platform of NGDOs.

Mostly answered by females, with qualifications at higher education level and of Portuguese nationality, we have identified as the most important values that should guide individual and collective action of the actors in the Cooperation, the following: being supportive, responsible, open, honest, capable, transparent, having integrity, showing respect, looking for social justice, excellence, freedom, equality and a world at peace (Annex 1).

\section{Analysis 3:}

In terms of this analysis, it is important to emphasize that the overwhelming majority of public and private actors of the Portuguese Cooperation system remain after the merger, as: the Parliament; immigrant associations; municipalities and social responsibility of companies (when they exercise or have activities related to Cooperation); universities and polytechnics institutes; foundations, sports, leisure and friends groups; firefighters; Government; Regional Governments; Ministries as Finance, Economy, Solidarity, Employment and Social Security, and Justice; NGOs and NGDOs; confessional organizations; unions; FCD (Sangreman 2009, 58; Sangreman and Faria 2015, 82-87).

Apart from these, and in the context of post-merger, adds up the Camões-ICL, and this, in the current scenario, can see his power, functions and pretensions limited 
by a set of conditions that characterise the political and socio-economic realities. In Sangreman and Faria $(2015,118)$, exists the only rich picture we know that want to portray the power of different public and private organizations within the Portuguese Cooperation system. Is this type of analysis that allows to consider the public and private actors, together, when considering problematic situations and investigate possible answers.

\section{Rich picture:}

Developed on the basis of what we nicknamed "5 (five) eggs of Cooperation, as analogy to eggs for making omelets. The 5 (five) eggs are a type of essential actors for the existence of Cooperation. Without these, the Cooperation does not exist.

With these images created, and comparing the before $(t)$ and the after $(t+1)$, we easily identify the consequences of change nature of the main configurator in the entire system (IPAD to Camões-ICL) and we can put change hypothesis.

We observe, for example, the impact that this change has at the level of actors in Cooperation, which move away from the center with the economic diplomacy and the language to be defined as priorities in the foreign and Cooperation policies.

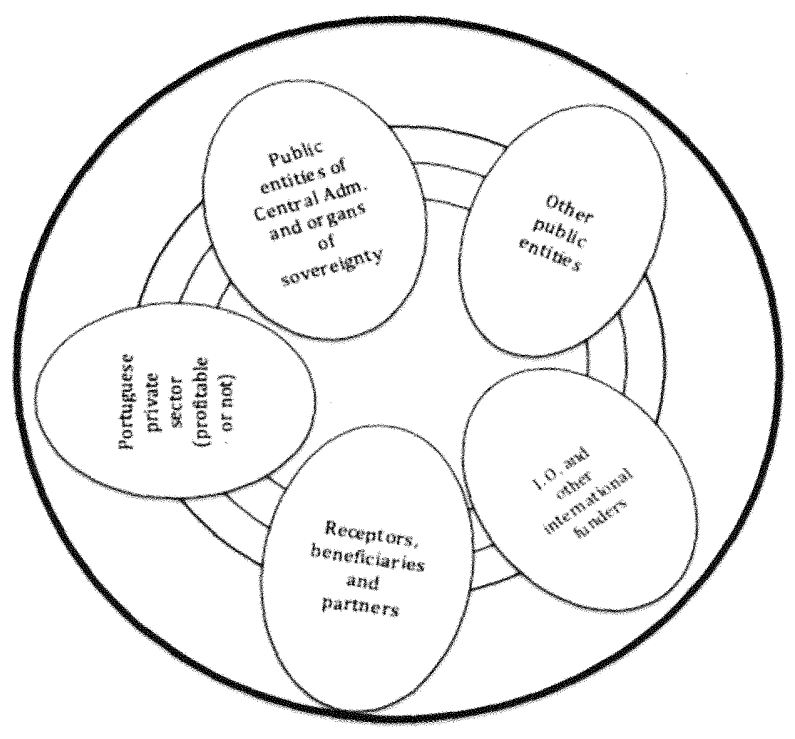

SCHEME 4 


\section{Conceptual model:}

From the summary provided at time $\mathrm{t}$ - "Finance and influence $(\mathrm{P})$ according to the knowledge (that the A1, A2 and A3 analysis allow) and the existing vision $(\mathrm{Q})$, to execute $(\mathrm{R})$, and evaluate before deciding what changes should be made to resume financing and influence" - constructed from the Analysis 1, 2 and 3, and taking into account the changes in the relevant activity system (after the merger of the IPAD and the Camões Institute), we developed a new acronym PQR [P - reconfigure the Portuguese Cooperation system after the merger of 2 (two) different organisms, the IPAD and the Camões Institute in the Camões-ICL; $\mathrm{Q}$ - by the creation of a Council of Ministers for Cooperation, and a Council for Social Dialogue of Cooperation, Language and Economic Diplomacy, such as by defining new priorities of a new Cooperation strategy; $\mathrm{R}$ - in order to reach a structure and a Cooperation policy guided by sustainability, consistency and effectiveness] and we identify the elements of CATWOE mnemonic (Clients: PALOPs, East Timor and Brazil; Actors: MNE/Camões-ICL, NGOs, local administrations, associations, institutes, polytechnic institutes, universities, churches, foundations...; Transformation Process [Cooperation model before the merger (input) and Cooperation model post-merger (output)]; Weltanschauung/Environmental constraints (Portuguese Cooperation as the main and European and global Cooperation as secondary); Owners (MNE/Camões-ICL and the big foundations [FCGulbenkian and Foundation Oriente, mainly]).

With the identification of these elements, it was possible to set a new root definition and a new synthesis at moment $\mathrm{t}+1$ [reconfigure the Portuguese Cooperation system after the merger of 2 (two) different organisms, the IPAD and the Camões Institute in the Camões-ICL, by the creation of a Council of Ministers for Cooperation, and a Council for Social Dialogue of Cooperation, Language and Economic Diplomacy, such as by defining new priorities of a new Cooperation strategy in order to reach a structure and a Cooperation policy guided by sustainability, consistency and effectiveness].

It's about this new modeling and an evaluation of the evolution between moments $t$ and $t+1$ (ie. an evaluation of the period between the moment of the merger and the present), which can focus the placement of different hypothesis of evolution of system in the near future and the predicted effects of the implementation of these hypothesis.

So, we have a thought structured framework with a reliable and operational scientific consistency. 


\section{Conclusion}

The present research resulted from the growing need to create a model which would make it possible to obtain an overall understanding of Portuguese Cooperation and "break" from the values that are normally identified by governments, based on documentation put together by international leaders.

With this we were able not only to put together this model but also to identify the values that the actors in Cooperation consider to be the guiding principles for individual and collective action in Portuguese Cooperation (being supportive, responsible, open, honest, capable, transparent, having integrity, showing respect, looking for social justice, excellence, freedom, equality and a world at peace). This enabled us to put together a standardised set.

Over and above this, we were able to show that SSM, as a methodology that is crucial for planning, and is normally used for business management, can be used in other very different scenarios, such as the policy underlying Portuguese Cooperation.

Indeed, the similarity between Portuguese Cooperation and soft systems, the way that it was possible to use its range of tools (gaining a clearer view of Cooperation in a whole series of aspects), and track its phases, showed us that SSM can really be used in such a different scenario as Portuguese Cooperation to put chances of improving the system and predict it's consequences.

\section{Bibliography}

Afonso, Maria, and Ana Fernandes. 2005. ABCD Introdução à Cooperação para o Desenvolvimento. Lisboa: IMVF and OIKOS;

Assembleia da República. 2002. Cooperação parlamentar de Portugal com os Países de Língua Portuguesa. Portugal: Assembleia da República;

Basden, Andrew, and A. Wood-Harper. 2006. "A Philosophical discussion of the root definition in Soft Systems Thinking: an enrichment of CATWOE". Systems Research and Behavioral Science, vol. 23, no. 1 (January-February): 61-87;

Bellini, Carlo, Ionara Rech, and Denis Borenstein. 2004. "Soft Systems Methodology: uma aplicação no "Pão dos Pobres" de Porto Alegre". RAE-eletrônica, vol. 3, no. 1 (January-June). Accessed September 12, 2012. http://www.scielo.br/pdf/raeel/v3n1/v3n1a06.pdf;

Bergvall-Kâreborn, Birgitta, Anita Mirijamdotter, and Andrew Basden. 2004. "Basic principles of SSM modeling: an examination of CATWOE from a soft perspective". Systemic Practice and Action Research, vol. 17, no. 2 (April): 55-73; 
Bergvall-Kâreborn, Birgitta, Anita Mirijamdotter, and Andrew Basden. 2003. "Reflections on Catwoe, a Soft Systems Methodology technique for systems design". In Towards a new interdisciplinarity: proceedings of the 9th annual working conference of CPTS, edited by Rob Nijhoff, Sytse Strijbos and Birgitta Bergvall-Kâreborn. Amersfoort: CPTS;

Bergvall-Kâreborn, Birgitta. 2002. "Enriching the model-building phase of soft systems methodology". Systems research and behavioral science, vol. 19, no. 1 (January-February): 27-48;

Bergvall-Kâreborn, Birgitta. 2001. "The role of the qualifying function concept in systems design". Systemic practice and action research, vol. 14, no. 1 (February): 79-93;

Bergvall-Kâreborn, Birgitta, and Anita Grahn. 1996. "Expanding the framework for monitor and control in Soft Systems Methodology". Systems practice, vol. 9, no. 5 (October): 469-495;

Castelo Branco, Luís, and Joaquim Dias. 2009. O cluster da ilha de Moçambique e a recuperação da fortaleza de S. Sebastião. Lisboa: IPAD;

Boulding, Kenneth. 2004. "General systems theory - the skeleton of science". E:CO Special Double Issue, vol. 6, no. 1-2: 127-139.

CEAUP. 2012. Revista africana studia, n. ${ }^{\circ} 18,1 .^{\circ}$ semestre. Porto: Centro de Estudos Africanos da Universidade do Porto;

Checkland, Peter. 1981 (ed. 1991). Systems Thinking, systems practice. Chichester: John Wiley;

Checkland, Peter, and Jim Scholes. 1990. Soft Systems Methodology in action. Chichester: John Wiley;

Checkland, Peter, and John Poulter. 2006. Learning for action. Chichester: John Wiley;

Curo, Rocio, and Mischel Belderrain. 2011. "A evolução dos estágios do processo sistémico em Soft Systems Methodology". Paper presented at the Anais do 7. ${ }^{\circ}$ Congresso Brasileiro de Sistemas - Uni-FACEF Centro Universitário Municipal de Franca, Franca, São Paulo. Accessed September 16, 2012. http://www.academia.edu/1046965/A_evolucao_dos_estagios_no_processo_sistemico_em_SSM;

DAC/OCDE. 2011. Development Co-operation, report 2011, 50th Anniversary Edition. Paris: OECD Publishing;

DAC/OECD. 2010. Portugal: Development Assistance Committee (DAC): peer review 2010. [Paris]: OECD Publishing;

Ellerman, David. 2009. Helping people helping themselves. EUA: The University of Michigan Press;

Faria, Raquel. 2014. "A Cooperação Portuguesa no contexto da Cooperação Internacional para o Desenvolvimento (1998-2012): um ensaio de modelização". PhD diss., University of Coimbra;

Freitas, Jonathan, Márcio Cota Júnior, and Lin Cheng. 2008. "O Soft System Thinking e a Soft Systems Methodology". Paper presented at the $4 .{ }^{\circ}$ Congresso Brasileiro de Sistemas Uni-FACEF Centro Universitário Municipal de Franca, Franca, São Paulo, October 29-30. Accessed September 16, 2012. http://legacy.unifacef.com.br/quartocbs/artigos/A/A_114.pdf; 
Hardman, Julie, and Alberto Paucar-Caceres. 2011. "A Soft Systems Methodology (SSM) based framework for evaluating managed learning environments". Systemic practice and action research, vol. 24, no. 2 (April): 165-185;

High, Chris, and Guszt Nemes. 2009. "Purpose and perspective: using soft systems methods in stakeholder analysis". Paper presented at the EASY-ECO Budapest Conference 2009: Stakeholder Perspectives in Evaluating Sustainable Development, Budapest, Hungary, October 16-18. Accessed September 18, 2012. http://oro.open.ac.uk/25826/5/High2009a.pdf;

Hoss, Marcelo. 2011. "Soft Systems Methodology como forma de operacionalizar o processo de transformação Lean sob a perspectiva da escola de pensamento evolucionária: uma pesquisa-ação". PhD diss., Federal University of Rio Grande do Sul;

IPAD. 2011. Cooperação Portuguesa, uma leitura dos últimos quinze anos de cooperação para o desenvolvimento (1996-2010). Lisboa: IPAD;

McElroy, Jerome, and Leslie Morris. 2002. "African island development experiences: a cluster of models". Bank of Valleta review, no. 26 (Autumn): 38-57;

Mingers, John, and Sarah Taylor. 1992. "The use of Soft Systems Methodology in practice". The Journal of the Operational Research Society, vol. 43, no. 4 (April): 321-332;

Mingers, John. 2000. "A idea ahead of its time, the history and development of Soft Systems Methodology". Systematic Practice and Action Research, vol. 13, no. 6 (December): 733-755;

Mirijamdotter, Anita, and Birgitta Bergvall-Käreborn. 2006. "An appreciative critique and refinement of Checkland's Soft Systems Methodology". In In search of an integrative vision for technology: interdisciplinary studies in information systems, edited by Sytse Strijbos and Andrew Basden, 79-102. New York: Springer Science + Business Media, Inc.;

MNE. 2005. Uma visão estratégica para a Cooperação Portuguesa. Lisboa: IPAD;

Monteiro, Ramiro. 2001. A África na política de Cooperação Europeia. 2. ${ }^{a}$ ed. atual.. Lisboa: Universidade Técnica de Lisboa - Instituto Superior de Ciências Sociais e Políticas;

Nunes, Giane. 2008. "Aprendizagem sistêmica para o desenvolvimento turístico em Praia Grande (SC): uma reflexão a partir da SSM - Soft Systems Methodology". Master's diss., Federal University of Santa Catarina;

Oliveira, Ana. 2014. "Avaliação de programas de desenvolvimento - acima de tudo um processo de aprendizagem". In Os actores não governamentais na avaliação - exemplos práticos em Moçambique e Guiné-Bissau, coordinated by Carlos Sangreman, 15-37. Lisboa: CEsA;

OCDE. 2006. Harmonising Donor Practices for Effective Aid Delivery. Paris: OECD Publishing;

Palma, Elisabete. 2002. "A política de Cooperação Portuguesa”. Janus-online. Accessed May 8, 2012. http://janusonline.pt/economia/economia_2002_3_3_6_c.html\#1;

Pidd, Michael. 1998. Modelagem empresarial. Porto Alegre: Bookman;

Proença, Fátima. 2009. "Avaliando a Cooperação descentralizada: pistas para um modelo com aplicação empírica". In A Cooperação descentralizada e as dinâmicas de mudança em países africanos - os casos de Cabo Verde e da Guiné-Bissau, coordinated by Carlos Sangreman, 137-179. Lisboa: CEsA and ACEP; 
Rossoni, Luciano. 2006. "Modelagem e simulação soft em estratégia = Soft modelling and simulation in strategy". Revista produção online, vol. 6, n. ${ }^{\circ} 2$ (August). Accessed September 16, 2012. producaoonline.org.br/rpo/article/download/291/367;

Sagasti, Francisco, and Gonzalo Alcalde. 1999. "The shape of things to come: development-cooperation themes, organizations, and resources". In Development Cooperation in a fractured global order: an arduous transition, by Francisco Sagasti and Gonzalo Alcalde, 146-155. Canada: IDRC;

Salner, Marcia. 1999. "Beyond Checkland \& Scholes: improving SSM". Paper presented at the 17th International Conference of The System Dynamics Society and the 5th Australian \& New Zealand Systems Conference, Wellington, New Zealand, July 20-23. Accessed September 16, 2012. http://www.systemdynamics.org/conferences/1999/PAPERS/PLEN3.PDF;

Sangreman, Carlos, and Raquel Faria. 2015. "Uma leitura síntese da Cooperação portuguesa". In O cluster como instrumento teórico e prático da Cooperação Internacional para o Desenvolvimento portuguesa: o caso de Moçambique, Timor-Leste, São Tomé e Príncipe e Angola, coordinated by Carlos Sangreman, 65-140. Lisboa CEsA-ISEG/ULisboa and CEI-ISCTE/IUL;

Sangreman, Carlos. 2009. "A teoria da Cooperação Internacional para o Desenvolvimento e o estado de arte da Cooperação Portuguesa". In A Cooperação descentralizada e as dinâmicas de mudança em países africanos - os casos de Cabo Verde e da Guiné-Bissau, coordinated by Carlos Sangreman, 25-97. Lisboa: CEsA and ACEP;

Sangreman, Carlos. 2006. "O instrumento de transformação da Cooperação Portuguesa: os clusters, o que são e como se podem operacionalizar". Cooperação, no. 1, series 2 (December): 31-34. Lisboa: IPAD;

Ulrich, Werner. 1998. Systems Thinking as if people mattered: critical Systems Thinking for citizens and managers. Working Paper no. 23. Lincoln: Lincoln School of Management, University of Lincolnshire \& Humberside, now University of Lincoln;

Vickers, Geoffrey. 1965. The art of judgment. London: Chapman \& Hall.

Sources:

DAC mid-term review of Portugal: Lisbon, 17 December 2012. (Letter from CAD/OCDE to SNEC, 2013);

Paris Declaration on Aid effectiveness (published in 2006, by OECD);

Reports and documents about the cluster of East Timor (2011);

Reports, documents and maps about the cluster of Mozambique (2006). 
1. By "those working in Cooperation" we understand all those who are involved in activities relating to Cooperation and those who have the motivation to do so.

2 This has played a part in the increased numbers of players that can take different forms (NGO, municipal authorities, ministries, universities, polytechnics, the courts, foundations, cooperatives, churches, hospitals and so on).

3 Checkland uses this element to define the particular player who has the power to stop or modif the process of transformation/system. We believe that in a system of human activities it is necessary to differentiate the power of stopping the operating model. In our view; the latter only exists on rare occasions and do not exist in the cooperation system.

4. It should be noted that the models can vary according to the view that the observers har'e of the real situation. The models are above all parts of a debate on systems of human activities. The same is true for some of the variables in CATWOE, among them the view of, and relative weight given to, the values for each kind of actor.

5. Ethics and Elegance.

6. This comparison should be undertaken with the «stakeholders involved in the situaiton and interested in improving it», in such a way as to lead to discussions on the desired and culturally possible changes that may be undertaken, improving the problem situation in this way (Checkland in Curo and Belderrain 2011,34).

7. See list of actors in Sangreman and Faria (2015).

8 For a detailed vision consult: Faria, Raquel. 2014. "A Cooperação Pörtuguesa no contexto da Cooperação Internacional para o Desenvolvimento (1998-2012): um ensaio de modelização”. PhD diss., University of Coimbra. Available at: https://estudogeral.sib.uc.pt/jspui/handle/10316/23918

9. January 20 to February 20, 2013. Annex 1 - The values of those working in Portuguese Cooperation, in graphic term 
ANNEX 1. The values of those working in Portuguese Cooperation, in graphic term
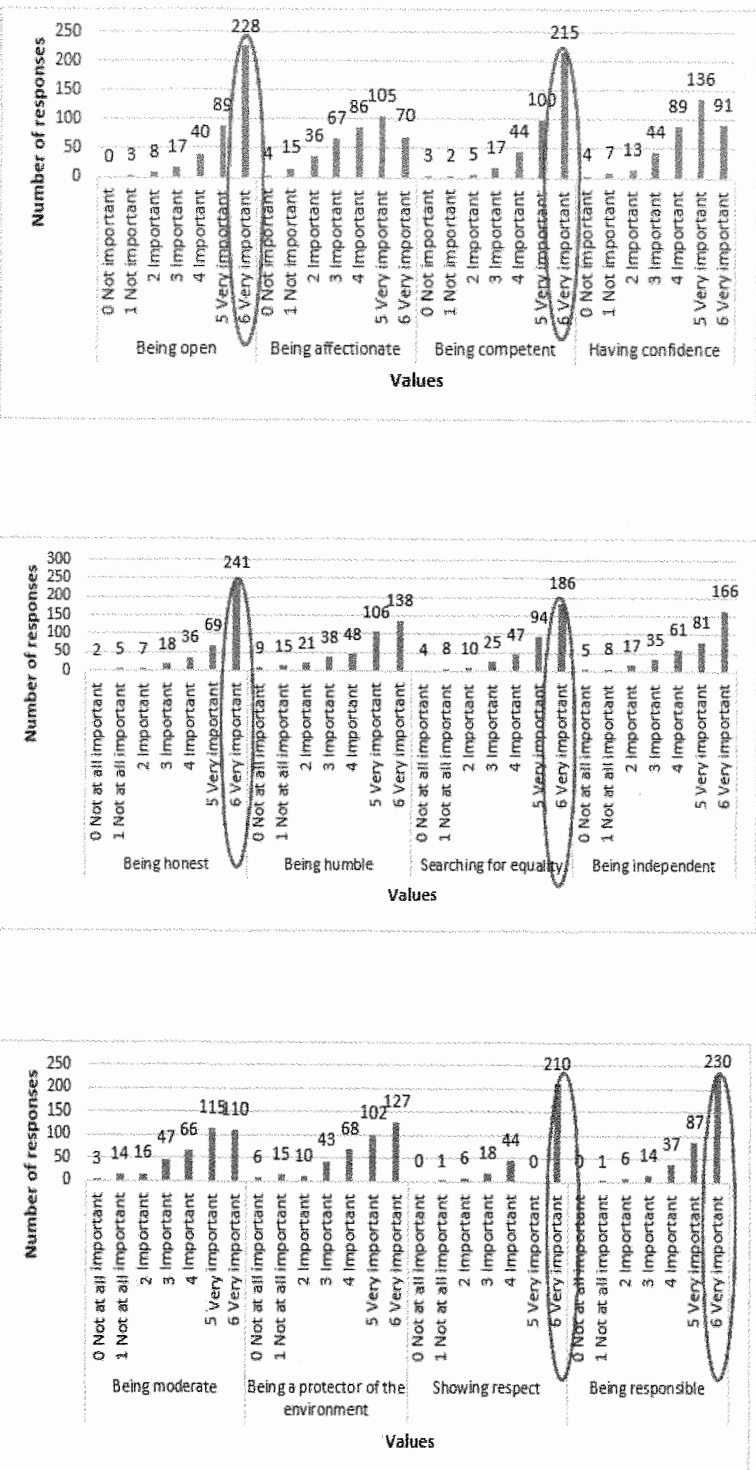
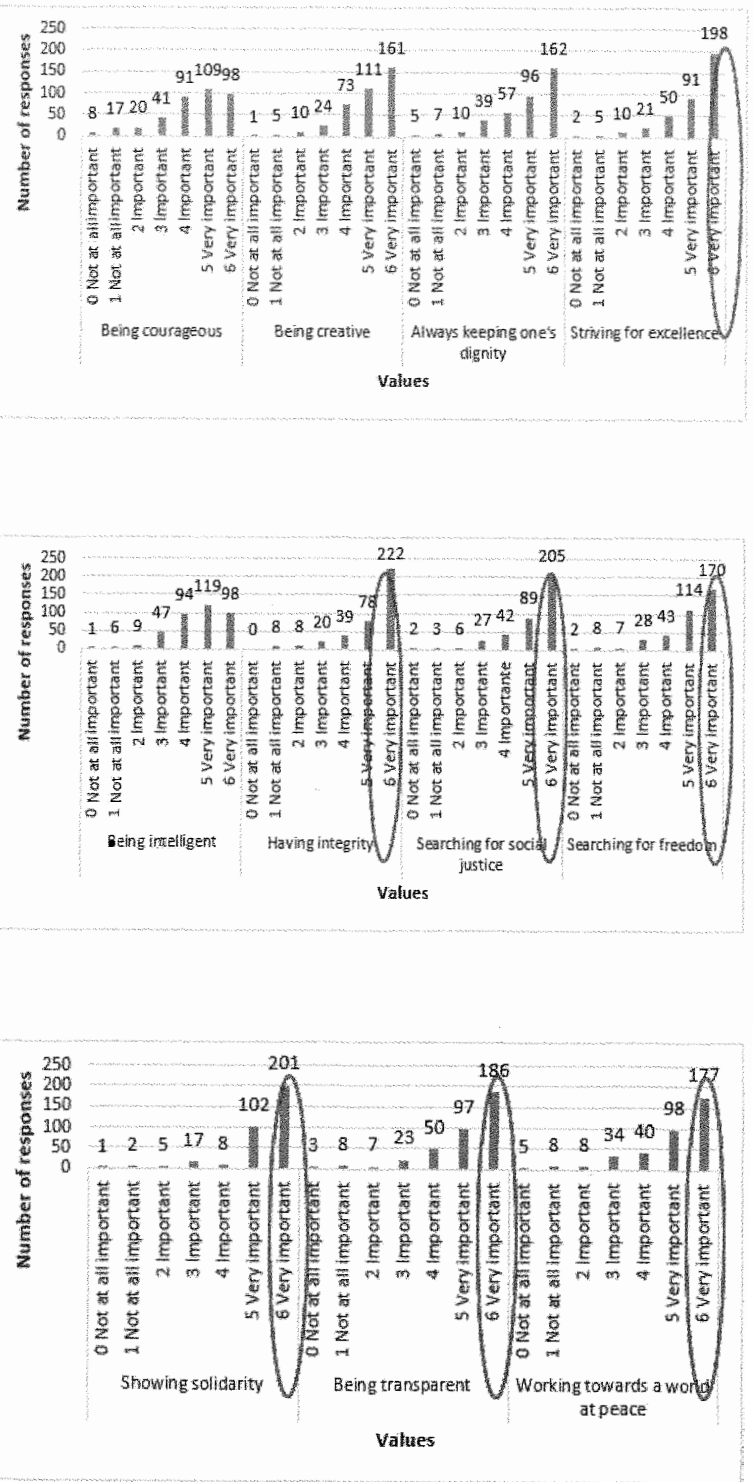
ANNEX 2. Summary table

\begin{tabular}{|c|c|c|c|}
\hline CATWOE & Analysis & $\begin{array}{l}\text { Operational } \\
\text { model }\end{array}$ & $\begin{array}{l}\text { Examples of } \\
\text { questions or } \\
\text { problematic } \\
\text { situations }\end{array}$ \\
\hline $\begin{array}{l}\text { (C) Clients, Bene- } \\
\text { ficiaries, partners } \\
\text { (A) Actors invol- } \\
\text { ved } \\
\text { (T) Transforma- } \\
\text { tion or evolution } \\
\text { (financial, human, } \\
\text { organizational) } \\
\text { (W) Vision and } \\
\text { values } \\
\text { (O) Main actors } \\
\text { or system configu- } \\
\text { rator } \\
\text { (E) External en- } \\
\text { vironment to the } \\
\text { system (politics in } \\
\text { general, foreign } \\
\text { policy, European } \\
\text { Union, United } \\
\text { Nations, OTAN; } \\
\text { analysis of the po- } \\
\text { litical, social and } \\
\text { economic situa- } \\
\text { tion of the partner } \\
\text { countries) }\end{array}$ & $\begin{array}{l}\text { A1 } \\
\text { Factual analysis } \\
\text { of the evolution of } \\
\text { Portuguese Coope- } \\
\text { ration between the } \\
\text { moment } t \text { and } t+1 \\
\text { A2 } \\
\text { Social analysis } \\
\text { of the national } \\
\text { and international } \\
\text { external environ- } \\
\text { ment in which } \\
\text { there is Coopera- } \\
\text { tion } \\
\text { A3 } \\
\text { Analysis of power } \\
\text { relations between } \\
\text { actors in the Coo- } \\
\text { peration system } \\
\text { Rich Picture } \\
\text { Graphic expres- } \\
\text { sion of analysis } \\
\text { done }\end{array}$ & $\begin{array}{l}\text { "Finance and } \\
\text { influence (P) ac- } \\
\text { cording to the } \\
\text { knowledge (that } \\
\text { the A1, A2 and A3 } \\
\text { analysis allow) and } \\
\text { the existing vision } \\
\text { (Q), to execute (R), } \\
\text { and evaluate befo- } \\
\text { re deciding what } \\
\text { changes should be } \\
\text { made to resume } \\
\text { financing and in- } \\
\text { fluence" } \\
\text { Rich Picture } \\
\text { Graphic expression } \\
\text { of the model }\end{array}$ & $\begin{array}{l}\text { 1. We should conti- } \\
\text { nue with "Camões, } \\
\text { ICL" or should a) } \\
\text { Have again orga- } \\
\text { nism of Language } \\
\text { and Development } \\
\text { Agency; or should: } \\
\text { b) maintain Camões } \\
\text { but give a different } \\
\text { vision changing } \\
\text { priorities with more } \\
\text { importance from Co- } \\
\text { operation instead of } \\
\text { Language and Eco- } \\
\text { nomic Diplomacy? } \\
\text { 2. The clusters of } \\
\text { Cooperation can be } \\
\text { the center of inno- } \\
\text { vation of Portuguese } \\
\text { Cooperation? } \\
\text { 3. It's justified the } \\
\text { defined geographical } \\
\text { and thematic prio- } \\
\text { rities or we have to } \\
\text { differentiate by be- } \\
\text { neficiaries? }\end{array}$ \\
\hline
\end{tabular}

